\title{
Index for 1998
}

\section{Articles}

Comment vous appelez-vous? Why the French Change Their Names

James E. Jacob and Pierre L. Horn 3

Reading Names in an Elizabethan Allusion: Henry Wriothesley,

Earl of Southampton, and Thomas Nash.

D. Allen Carroll 29

Attitudes Toward Women's Marital Name Choices.

Laurie K. Scheuble and David R. Johnson 83

Children of the Satyrs: Naming Patterns of Leather and Levi Clubs.

Robert B. Marks Ridinger 97

The Other Nicknames of American Greek-Letter Organizations.

Thomas E. Murray 113

Akan Death-Prevention Names: A Pragmatic and Structural Analysis

Samuel Gyasi Obeng 163

The Terminology of Name Studies

Ladislav Zgusta 189

The Influence of Media on Given Names

Heidi Vandebosch 243

From Mocha Dick to Moby Dick: Fishing for Clues to

Moby's Name and Color

Ben Rogers 263

Rapanui Placenames: Keys to the Mysteries

Sergei V. Rjabchikov 277

Reviews

Place Names of Alberta. Volume IV (Northern Alberta).

Ed. Merrily K. Aubrey.

Sheila Embleton 42

The Place-Names of East Flintshire. By Hywel Wyn Owen.

W.F.H. Nicolaisen 50

Studier över sörmländska sjönamn. [Studies on the Lake Names

of Södermanland]. By Svante Strandberg. $\quad$ W.F.H. Nicolaisen 52

Proper Names in Modern Norwegian: A Grammar Study.

By M.L. Alëkshina.

Kenneth Womack 54

Pomístní jména v Čechách; o čem vypovídají jména polí, luk,

lesü, hor, vod a cest. [The Anoeconyms in Bohemia; or

What the Names of Fields, Meadows, Forests, Mountains,

Bodies of Water, and Roads Tell Us]. By L. Olivová-Nezbedová,

M. Knappová, J. Malenínská and J. Matúšová. Ladislav Zgusta 57

English place names. By Kenneth Cameron.

Victor Watts 63

Kentucky's Salt River Valley. By Robert M. Rennick. Kelsie B. Harder 66 From Red Hot to Monkey's Eyebrow. By Robert M. Rennick.

Kelsie B. Harder 67

Study of Placenames of Ongole Taluk. By P. Nagamalleswara Rao.

William Bright 69

The Surname Detective. By Colin Rogers.

C.M. Carnes 70

A Dictionary of Muslim Names. By Radwan Hakim.

Edwin D. Lawson 71

Jewish Family Names and Their Origins:

An Etymological Dictionary. By Heinrich W. Guggenheimer

and Eva H. Guggenheimer.

Edwin D. Lawson 133 
A Dictionary or Jewish Surnames from the Russian Empire.

By Alexander Beider.

Edwin D. Lawson 133

Jewish Surnames from Prague (15-18th Centuries).

By Alexander Beider.

Edwin D. Lawson 133

A Dictionary of Literary Pseudonyms in the English Language.

By T.J. Carty.

Leonard R.N. Ashley 139

Placenames of the World. Origins and Meanings of the Names for

Over 5000 Natural Features, Countries, Capitals, Territories,

Cities and Historic Sites. By Adrian Room.

Ladislav Zgusta and Dale Hartkemeyer 146

Exploring the Past Through Place-Names: Woolverstone.

By Sylvia Laverton.

W.F.H. Nicolaisen 149

The Place-Names of the Isle of Wight. By A.D. Mills. W.F.H. Nicolaisen 151 "Ökonymie." Zur Produktnamen-Linguistik im Europäischen

Binnenmarkt. ("Econymy:" On the Linguistics of Product

Names in the European Union.) By Christoph Platen. Ingrid Piller 208 Florida Place Names: Alachua to Zolfo Springs.

By Allen Morris

E. Wallace McMullen 216

Ortnamn $i$ språk och samhälle. Hyllningsskrift till Lars

Hellberg. (Placenames in Language and Society. Essays

in Honor of Lars Hellberg.) Svante Strandberg, ed. W.F.H. Nicolaisen 231

Reader zur Namenkunde III, 1 and III, 2: Toponymie.

Friedhelm Debus and Wilfried Seibicke, eds.

Reader zur Namenkunde IV: Namenkunde in der Schule.

(Onomastics in Education.) Eds. Rainer Frank and

Gerhard Koss.

W.F.H. Nicolaisen 234

The Surname as a Cultural Value and an Ethnic Heritage.

Tracing Your Polish Roots. By Zofia Kaleta.

Ladislav Zgusta 282

Polish Surnames: Origins and Meanings. By William F. Hoffman.

Ladislav Zgusta 287

These Are the Names: Studies in Jewish Onomastics. Eds. Aaron

Demsky, Joseph A. Reif and Joseph Tabory.

Carl S. Ehrlich 290

A Dictionary of Pseudonyms with their Origins, with Stories of

Name Changes. By Adrian Room.

Leonard R.N. Ashley 298

Kampf um Namen: Bernhard Weiss gegen Joseph Goebbles (The

Battle About Names: Bernhard Weiss versus Joseph Geobbels).

By Dietz Bering

W.F.H. Nicolaisen 305

Proceedings of the XIXth International Congress of Onomastic

Sciences. Ed. W.F.H. Nicolaisen

Lynn C. Hattendorf Westney 307

In Memoriam

Meredith F. "Pete" Burrill.

Richard R. Randall 37

Lurline H. Coltharp.

Grant Smith 205

Other

Proverbial Names of the Baganda.

Jonathan Musere 73

Herman Melville's Names: A Bibliography.

Ben Rogers 155 